\title{
Next-generation Sequencing with cerebrospinal fluid for the diagnosis of progressive multifocal leukoencephalopathy in HIV-infected patients
}

\author{
Renfang Zhang \\ Shanghai Public Health Clinical Center \\ Tangkai Qi \\ Shanghai Public Health Clinical Center \\ Jun Chen \\ Shanghai Public Health Clinical Center \\ Jianjun Sun \\ Shanghai Public Health Clinical Center \\ Li Liu \\ Shanghai Public Health Clinical Center \\ Wei Song \\ Shanghai Public Health Clinical Center \\ Zhenyan Wang \\ Shanghai Public Health Clinical Center \\ Yang Tang \\ Shanghai Public Health Clinical Center \\ Hong-zhou Lu ( $\square$ luhongzhou@fudan.edu.cn ) \\ Shanghai Public Health Clinical Center
}

\section{Research article}

Keywords: AIDS, HIV, progressive multifocal leukoencephalopathy $\mathbb{P}$ PL区, Next-generation Sequencing

Posted Date: September 8th, 2019

DOI: https://doi.org/10.21203/rs.2.14163/v1

License: (c) (i) This work is licensed under a Creative Commons Attribution 4.0 International License. Read Full License 


\section{Abstract}

Background To investigate the clinical manifestations, imaging findings, characteristics of cerebrospinal fluid, treatment and prognosis in patients with AIDS-related progressive white matter lesions diagnosed by second-generation sequencing with cerebrospinal fluid.

Methods Patients with clinically suspected PML were diagnosed by second-generation sequencing with cerebrospinal fluid, and the clinical data of these patients were retrospectively reviewed.

Results Ten patients with AIDS-related PML were diagnosed, including eight males (80\%). The average age was $38.7 \pm 8.2$ years, and the median CD4+ T cell count was 46×106/L. The median HIV RNA was $5.99 \times 104 \mathrm{copies} / \mathrm{ml}$. Main clinical manifestations included: dyskinesia in 4 patients (40\%) and dizziness in 3(30\%), cognitive decline in 2(20\%), and speech disorder in 1(10\%). Three patients (30\%) developed convulsions throughout the course of the disease. Image findings involved lesions cerebellum in 3 cases (30\%), and lesions above the cerebellum in 7 cases (70\%). Mild increase of total protein was observed in the cerebrospinal fluid of 4 cases (40\%), while white blood cell count, sugar and chloride were normal in all of the cases. The copies of JCV sequence in the cerebrospinal fluid ranged from 3-12531 reads (median=67 reads). All the patients received antiviral therapy including integrase inhibitors. Among the 10 patients, 2 died in hospital and 8 survived, 2 of them have survived for more than 1 year. Symptoms were improved in 5 patients and unchanged in 3 patients.

Conclusions PML is common in patients with HIVIAIDS. It is reliable to diagnose the disease through clinical manifestations, routine detection of cerebrospinal fluid, imaging and cerebrospinal fluid NGS sequencing. Strong and effective antiretroviral treatment may improve the prognosis of patients.

\section{Background}

Progressive multifocal leukoencephalopathy (PML) is a rare demyelinating disease of the central nervous system (CNS) caused by reactivation of the JC polyomavirus (JCV) which occurs almost exclusively in immunocompromised patients. In the preantiretroviral therapy (ART) era, 3-7\% of human immunodeficiency virus (HIV)-infected patients developed PML[1-3]. With the widespread use of ART, the incidence and mortality of PML have declined significantly[4-8]. PML typically manifested as altered mental status, motor deficits, ataxia, and visual symptoms and is progressive and usually fatal. Currently, no specific treatment is available, but restoration of immune function with ART may lead to disease remission or improved survival.

More importantly, diagnosis of PML in HIV-infected patient is still challenging due to the complicated clinical characteristics in late stage of diseases, various imaging manifestations and the sensitivity of JCV DNA detection in cerebrospinal fluid (CSF)[9, 10]. Next-generation sequencing technology has been successfully used in detecting pathogens in CSF[11-13]. Here, we reported a series of cases diagnosis of PML through detecting the JC virus in CSF using NGS in clinically suspected patients.

\section{Methods}

HIV-infected patients was suspected of PML by clinical manifestations, typical cranial imaging features and examination of CSF which rule out common CNS infections (e.g., cryptococcal meningitis, tuberculosis meningitis and toxoplasmic encephalitis). CSF of suspected patients was sent for NGS.

\section{$C D 4^{+} T$ cell count and HIV viral load}

CD4 T cell count and HIV viral load were quantified using flow cytometry with FACSCalibur (BD Company, USA) and COBAS AmpliPrep/COBAS TaqMan HIV-1 Test (Roche, Switzerland) at the clinical laboratory of SPHCC, respectively. 
Sterile cerebrospinal fluid (CSF) of patients was retained for high-throughput sequencing. The glass bead grinding process was carried out firstly. A glass bead with a diameter of $0.5 \mathrm{~mm}$ was added to the broken tube, and then $0.6 \mathrm{ml}$ of the sample was added in. The sample was vibrated at 2800-3200 rounds/minute for 30 minutes. Then $300 \mu$ was used for nucleic acid extraction. The genome extraction kit (DP316) of Tiangen microsample was operated according to the instructions. Five hundred nanogram of extracted DNA was interrupted, repaired, jointed, amplified, repositored and sequenced according to the standard process. A CSF sample produced 20M sequence data. Low-quality and short sequence (less than $35 \mathrm{bp}$ ) was removed from the sequence data, so as to obtain high-quality sequence. The sequence was then compared with the human reference genome (H19), with the software of Burrows-Wheeler Alignment. After removing the human sequence, the sequence was compared with 4 databases of bacteria (2473 species), fungi (199 species), viruses (4061 species) and parasites (135 species), and the numbers of sequences matched to any a certain pathogen were obtained. The possible pathogens were judged according to the number of sequences and other clinical judgement.

\section{Treatment and follow-up}

Patients with positive JCV in CSF were diagnosis of PML. ART were continued during hospitalization or initiated immediately after exclusion of the previous-mentioned common CNS infection. Patients were followed-up on the outpatient clinic or by phone call. Patients with aggravation of clinical symptoms and CD4 count increase following ART were diagnosis of immune reconstruction syndrome (IRIS) after excluded other causes.

\section{Statistical methods}

Descriptive analysis to describe demographic data. The baseline characteristics of patients were described by median values with continuous variables. The classified variables were counted and proportioned. All the data were processed using STATA 13 software (StataCorp, Texas, USA).

\section{Results}

Basic information of patients:

From Oct 2017 to Jan 2019, a total of 10 cases were diagnosed of PML, including eight males (80\%) and two females (20\%). These patients were at their middle age (38.7 \pm 8.2 years) with advanced immunodeficiency (CD4 T cell count 46 (2-241) cells/ml). HIV RNA was detectable in the majority patients (80\%). The value of HIV RNA was ranged from less than 40 to 2.81 $\star 10^{5}$ copies $/ \mathrm{ml}$, with a median of $5.99 * 10^{4}$ copies $/ \mathrm{ml}$.

HIV infection was not diagnosed until onset of PML symptoms in four patients. Two patients never received ART although HIV infection has been diagnosed for 6 and 8 years, respectively. Two patients who had resistance to current ART regimens developed symptoms after ART for 6 months and 12 years, with HIV viral load of $1.3 * 10^{5} \mathrm{copies} / \mathrm{ml}$ and $2.3 * 10^{4} \mathrm{copies} / \mathrm{ml}$, respectively. One patient developed symptoms after 1 month of ART. Two cases were complicated with pulmonary nontuberculosis Mycobacterium infection, and no other co-infection was found in all the patients.

\section{Symptom, imaging and CSF examination}

The onset of the disease is occult, gradually aggravated. The time from symptoms onset to admission was $0.5-3$ months. Dyskinesia (40\%), convulsions (30\%), dizziness (30\%), cognitive impairment (20\%) and speech impairment (10\%) were the most common symptom. Symptoms in case 9 were related to immune reconstruction syndrome after antiviral therapy. (See Table 1) 
Lesions were found in various parts of the brain in MRI examination. The lesions were located under the tentorium cerebellum in 3 cases (30\%) and above the tentorium cerebellum in the rest (70\%) (see Figure 1). For CSF test, levels of white blood cell, glucose and chloride were normal while slight increase of protein was observed in four patients (40\%).

JCV sequence in the cerebrospinal fluid varied from 3-12531 reads, median 67 reads (see Table 2).

\section{Treatment}

All patients received ART. Four of them started antiretroviral treatment immediately, 4 had been already treated for 1-3 months, 2 adjusted regimen according to drug resistance reports. Either raltegravir or dolutegravir was included in the regimen for every patient. Three patients received quadruple regimen to strengthen antiviral therapy. Supportive treatment were also given to alleviate symptoms.

\section{Therapeutic Response}

Two patients died at 2 and 5 months after onset of symptoms respectively. The remaining 8 cases survived and were followedup for 2-18 months. Two patients had survived for more than one year. Symptoms in five of the patients were relieved, but did not improve in the other three patients.

\section{Discussion}

The diagnosis of PML can be challenging in HIV-infected patients as variable CNS infections and tumors can presents in the late stage of immunodeficiency. The clinical manifestations of PML can be varying, depending on the size, location and number of lesions. The most common symptoms in the current study included limb dyskinesia, dizziness and convulsions, which are neither sensitive nor specific. Cranial MRI can be helpful to identify the white matter lesions of PML. Frontal lobes and parietooccipital regions are the regions that most affected. However, in HIV-infected patients, many other diseases including tuberculosis meningitis, cytomegalovirus infection, varicella-zoster leukoencephalitis, CNS vasculitis, as well as AIDS dementia may affect the white matter in a similar manner.

Routine CSF analysis is helpful to diagnose CNS infections. It has been reported that CSF white blood cells counts generally below 20/ul while protein level can be elevated in HIV-infected patients with PML[14, 15]. However, other infections including viral infection, tuberculosis infection, as well as fungi infection can also lead to this change of CSF. Detection of JCV in cerebrospinal fluid by PCR is essential for confirming PML as autopsy of brain maybe difficult. In patients without ART, the sensitivity and specificity of this technique were $72-92 \%$ and $92-100 \%$, respectively $[9,10,16]$. The sensitivity may be restricted by the concentration of DNA in the CSF and the volume of CSF obtained. Frequent lumbar puncture for testing is not always convenient, since the volume of CSF is usually small and the number of suspected pathogens is high. More importantly, not all the clinicians would suspect PML in symptomatic HIV-infected patients. Therefore, JCV PCR may not be performed and patients maybe misdiagnosed and treated.

NGS can identify pathogenic microorganisms by high throughput screening, which can overcome the shortage of CSF volume. Taking full advantage of unbiased sequencing, NGS could also detect JCV in CSF "unexpectedly" in clinic where physicians are not aware of PML. In addition, NGS could provide result in a short time which could facilitate clinical management as delays in CNS infection and misdiagnosis can be fatal. In the current study, we reported for the first time a series of suspected PML cases confirmed diagnosis by NGS with CSF. Our results implicated that NGS could be a useful to help diagnose PML in HIV-infected patients. 


\section{Conclusions}

PML is prevalent in AIDS patients. NGS sequencing of the CSF may be a resolution for confirmation the diagnosis, combine with clinical and radiological findings, as well as routine examination of the CSF.

\section{Abbreviations}

PML: Progressive multifocal leukoencephalopathy; CNS: central nervous system; JCV: JC polyomavirus; ART: antiretroviral therapy ; HIV: human immunodeficiency virus; CSF: cerebrospinal fluid; IRIS:immune reconstruction syndrome.

\section{Declarations}

-Ethics approval and consent to participate

This study was approved by the Ethic Committee of Shanghai Public Health Clinical Center. Written informed consent were obtained from all the study patients.

-Consent for publication

Written informed consent to publish this information was obtained from study participants.

-Availability of data and material

Not applicable.

-Competing interests

There is no competing interests to be declared.

-Funding

Not applicable.

-Authors' contributions

Conceived and designed the research: HZL,RFZ. Analyzed the data: RFZ,TKQ, JC,JJS,LL,WS,ZYW,YT. Wrote the paper:RFZ, TKQ, JC,JJS. All authors drafted the article, revised it critically for important intellectual content, and approved the final article.

-Acknowledgements

We give our thanks to the colleagues of HIV health care clinic and the staff in the Department of Infectious Disease of Shanghai Public Health Clinical Center. We also give our cordially thanks to those patients participated in our research.

\section{References}

1. PETITO CK, CHO E, LEMANN W, NAVIA BA, PRICE RW: Neuropathology of Acquired Immunodeficiency Syndrome (AIDS). J NEUROPATH EXP NEUR 1986, 45(6):635-646.

2. Anders KH, Guerra WF, Tomiyasu U, Verity MA, Vinters HV: The neuropathology of AIDS. UCLA experience and review. AM J PATHOL 1986, 124(3):537-558.

3. Lang W, Miklossy J, Deruaz JP, Pizzolato GP, Probst A, Schaffner T, Gessaga E, Kleihues P: Neuropathology of the acquired immune deficiency syndrome (AIDS): a report of 135 consecutive autopsy cases from Switzerland. ACTA NEUROPATHOL 1989, 77(4):379-390.

4. Severe and complicated malaria. World Health Organization, Division of Control of Tropical Diseases. Trans $R$ Soc Trop Med Hyg 1990, 84 Suppl 2:1-65.

5. Greenberg AE, Ntumbanzondo M, Ntula N, Mawa L, Howell J, Davachi F: Hospital-based surveillance of malaria-related paediatric morbidity and mortality in Kinshasa, Zaire. Bull World Health Organ 1989, 67(2):189-196. 
6. Molyneux ME, Taylor TE, Wirima JJ, Borgstein A: Clinical features and prognostic indicators in paediatric cerebral malaria: a study of 131 comatose Malawian children. Q J Med 1989, 71(265):441-459.

7. English M, Sauerwein R, Waruiru C, Mosobo M, Obiero J, Lowe B, Marsh K: Acidosis in severe childhood malaria. QJM 1997, 90(4):263-270.

8. Marsh K, Forster D, Waruiru C, Mwangi I, Winstanley M, Marsh V, Newton C, Winstanley P, Warn P, Peshu N et al: Indicators of life-threatening malaria in African children. N Engl J Med 1995, 332(21):1399-1404.

9. Koralnik IJ, Boden D, Mai VX, Lord Cl, Letvin NL: JC virus DNA load in patients with and without progressive multifocal leukoencephalopathy. NEUROLOGY1999, 52(2):253-260.

10. Cinque $P$, Scarpellini $P$, Vago L, Linde A, Lazzarin A: Diagnosis of central nervous system complications in HIV-infected patients: cerebrospinal fluid analysis by the polymerase chain reaction. AIDS 1997, 11(1):1-17.

11. Wilson MR, Naccache SN, Samayoa E, Biagtan M, Bashir H, Yu G, Salamat SM, Somasekar S, Federman S, Miller S et al: Actionable diagnosis of neuroleptospirosis by next-generation sequencing. N Engl J Med 2014, 370(25):2408-2417.

12. Parize P, Muth E, Richaud C, Gratigny M, Pilmis B, Lamamy A, Mainardi JL, Cheval J, de Visser L, Jagorel F et al: Untargeted next-generation sequencing-based first-line diagnosis of infection in immunocompromised adults: a multicentre, blinded, prospective study. Clin Microbiol Infect 2017, 23(8):571-574.

13. Brown JR, Bharucha T, Breuer J: Encephalitis diagnosis using metagenomics: application of next generation sequencing for undiagnosed cases. J Infect 2018, 76(3):225-240.

14. Berger JR, Pall L, Lanska D, Whiteman M: Progressive multifocal leukoencephalopathy in patients with HIV infection. $J$ NEUROVIROL 1998, 4(1):59-68.

15. Berger JR, Levy RM, Flomenhoft D, Dobbs M: Predictive factors for prolonged survival in acquired immunodeficiency syndrome-associated progressive multifocal leukoencephalopathy. ANN NEUROL 1998, 44(3):341-349.

16. Hammarin AL, Bogdanovic G, Svedhem V, Pirskanen R, Morfeldt L, Grandien M: Analysis of PCR as a tool for detection of JC virus DNA in cerebrospinal fluid for diagnosis of progressive multifocal leukoencephalopathy. J CLIN MICROBIOL 1996, 34(12):2929-2932.

\section{Tables}

Table 1 Basic characteristic of patients with PML 


\begin{tabular}{|c|c|c|c|c|c|c|c|c|c|c|}
\hline $\begin{array}{l}\text { 'ase } \\
\text { no. }\end{array}$ & Age(year) & Gender & $\begin{array}{c}\text { Initial } \\
\text { symptom }\end{array}$ & $\begin{array}{c}\text { Time } \\
\text { from HIV } \\
\text { diagnosis } \\
\text { to PML } \\
\text { onset } \\
\text { (months) }\end{array}$ & $\begin{array}{c}\text { Time from } \\
\text { ART initiation } \\
\text { to PML } \\
\text { onset(months) }\end{array}$ & $\begin{array}{c}\text { CD4 } \\
(\text { cell } / \mu l)\end{array}$ & $\begin{array}{l}\text { HIVRNA } \\
\text { (copy/ml) }\end{array}$ & $\begin{array}{l}\text { Site of lesions } \\
\text { on MRI }\end{array}$ & Outcome & $\begin{array}{l}\text { Survival } \\
\text { time }\end{array}$ \\
\hline 1 & 24 & Female & Ataxia & 72 & 0 & 55 & Undo & $\begin{array}{l}\text { Right annular } \\
\text { protuberance }\end{array}$ & $\begin{array}{l}\text { Survived, } \\
\text { not } \\
\text { relieved }\end{array}$ & $>9$ months \\
\hline 2 & 38 & Male & $\begin{array}{l}\text { Slow } \\
\text { response }\end{array}$ & 0 & 0 & 2 & $2.81 \times 10^{5}$ & $\begin{array}{l}\text { Frontal lobe } \\
\text {,parietal lobe }\end{array}$ & $\begin{array}{r}\text { Survived, } \\
\text { relieved }\end{array}$ & $>4$ months \\
\hline 3 & 31 & Male & $\begin{array}{c}\text { Decreased } \\
\text { muscle } \\
\text { strength of } \\
\text { both lower } \\
\text { extremities }\end{array}$ & 3 & 0 & 46 & $\square 40$ & $\begin{array}{l}\text { Fronto, } \\
\text { temporal, } \\
\text { parietal, pillow } \\
\text { lobes }\end{array}$ & $\begin{array}{r}\text { Survived, } \\
\text { relieved }\end{array}$ & $>17$ months \\
\hline 4 & 48 & Male & $\begin{array}{c}\text { Right } \\
\text { Upper } \\
\text { Limb } \\
\text { Dyskinesia }\end{array}$ & 0 & 0 & 63 & $1.83 \times 10^{4}$ & multifocal & $\begin{array}{r}\text { Survived, } \\
\text { relieved }\end{array}$ & $>18$ months \\
\hline 5 & 42 & Female & Dysphonia & 144 & 144 & 16 & $2.30 \times 10^{4}$ & $\begin{array}{c}\text { Paraventricular } \\
\text { and fronto- } \\
\text { parietal lobes }\end{array}$ & Died & 3months \\
\hline 6 & 35 & Male & Dizzy & 0 & 0 & 4 & $1.35 \times 10^{5}$ & $\begin{array}{l}\text { Cerebellar, } \\
\text { hemisphere and } \\
\text { brainstem }\end{array}$ & Died & 2months \\
\hline 7 & 52 & Male & Dizzy & 96 & 0 & 46 & 209 & $\begin{array}{c}\text { Left brainstem, } \\
\text { cerebellopontine } \\
\text { angle }\end{array}$ & $\begin{array}{r}\text { Survived, } \\
\text { relieved }\end{array}$ & $>2$ months \\
\hline 8 & 37 & Male & $\begin{array}{l}\text { Right Limb } \\
\text { Dyskinesia }\end{array}$ & 6 & 6 & 241 & $1.3 \times 10^{5}$ & $\begin{array}{l}\text { Left cerebral } \\
\text { hemisphere }\end{array}$ & $\begin{array}{l}\text { Survived, } \\
\text { not } \\
\text { relieved }\end{array}$ & $\begin{array}{c}>9 \\
\text { months }\end{array}$ \\
\hline 9 & 44 & Male & $\begin{array}{l}\text { Left Limb } \\
\text { Dyskinesia }\end{array}$ & 1 & 1 & 117 & Undo & $\begin{array}{c}\text { Bilateral frontal, } \\
\text { temporal, } \\
\text { parietal lobes }\end{array}$ & $\begin{array}{l}\text { Survived, } \\
\text { not } \\
\text { relieved }\end{array}$ & $\begin{array}{c}>7 \\
\text { months }\end{array}$ \\
\hline 10 & 36 & Male & $\begin{array}{l}\text { Slow } \\
\text { response }\end{array}$ & 0 & 0 & 32 & $9.68 \times 10^{4}$ & $\begin{array}{c}\text { Frontal lobe, } \\
\text { right parietal } \\
\text { lobe }\end{array}$ & $\begin{array}{r}\text { Survived, } \\
\text { relieved }\end{array}$ & $\begin{array}{c}>3 \\
\text { months }\end{array}$ \\
\hline
\end{tabular}

Table 2 CSF routine tests 
Case no. White blood cell counts $\square \times 10^{6} 0 \mathrm{~L} \square$ glucose(mmol/L) chloride protein(mg/L) JCV sequence(reads)

\begin{tabular}{cccccc}
\hline $\mathbf{1}$ & 1 & 4.48 & 122 & 400 & 12531 \\
$\mathbf{2}$ & 0 & 2.35 & 123 & 554 & 667 \\
$\mathbf{3}$ & 2 & 2.77 & 122 & 228 & 17 \\
$\mathbf{4}$ & 5 & 2.85 & 123 & 581 & 59 \\
$\mathbf{5}$ & 3 & 2.99 & 122 & 342 & 75 \\
$\mathbf{6}$ & 4 & 2.6 & 118 & 697 & 193 \\
$\mathbf{7}$ & 2 & 2.5 & 122 & 268 & 9 \\
$\mathbf{8}$ & 4 & 3.91 & 119 & 494 & 81 \\
$\mathbf{9}$ & 1 & 4.06 & 131 & 260 & 3 \\
$\mathbf{1 0}$ & 10 & 2.79 & 133 & 398 & 12 \\
\hline
\end{tabular}

\section{Figures}

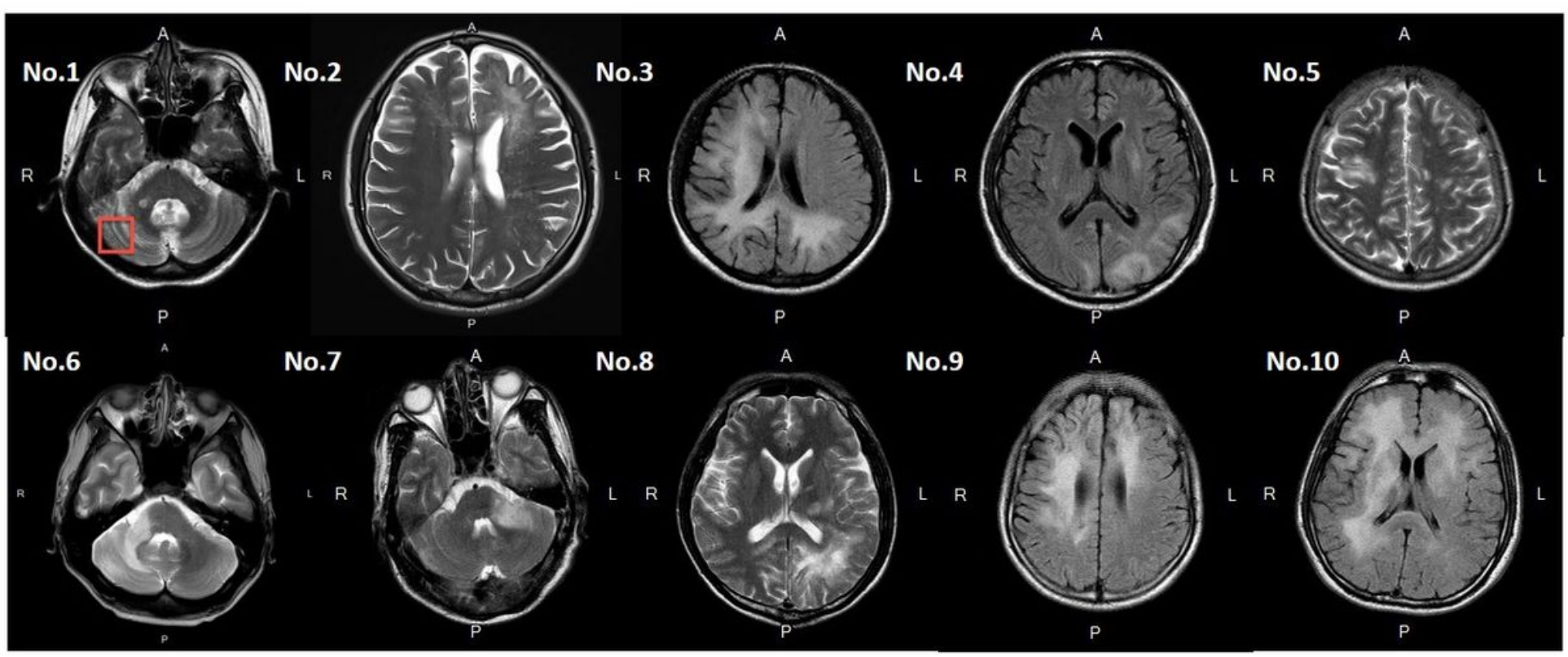

Figure 1

Lesions locations in the brains of all the cases 